\title{
Training Translators under the College English Course
}

\author{
Ping Qiu ${ }^{1, a^{*}}$ and $\mathrm{Na} \mathrm{Hu}^{1}$ \\ ${ }^{1}$ School of Foreign, Jingdezhen Ceramic Institute, Jingdezhen 333403, China \\ a45818682@qq.com
}

\begin{abstract}
Keywords: College English; Market demand; Translation teaching; Translation talents; Translation competence
\end{abstract}

\begin{abstract}
It's worthwhile to probe into the college English translation course mode, since the training of translators in universities has been unable to meet the needs of market. Nowadays, teachers begin to explore how to cultivate the reserve force of translation talents in college English teaching. This article first introduces the translation of some common sense, clear translation teaching the importance and urgency. Then, this paper presents the translation of the reserve forces in college English teaching non English majors, and analyzes the causes and possibilities. Applying the Output and Translation Competence Acquisition theories and looking into the problems in real translation teaching, this paper put forward the new course mode that is to combine the translation course with some other specialized courses. Firstly, some practical approaches and significance are presented, in addition, some teaching methods are also proposed in this paper.
\end{abstract}

\section{Introduction}

With the globalization of the world economy and the globalization of science and technology, China's foreign communication has expanded to various fields of the whole society economy, and has promoted the development of the world economy[1][2][3]. The translation industry of our country has begun to flourish and develop. But at present, China's translation talents are in short supply [4][5][6]. The existing translation talents cannot meet the demand of the translation market, and the gap of the translation talents is as high as $90 \%$, mainly because the teaching of translation has been neglected in universities[7][8]. Attaching great importance to translation teaching in college English teaching can provide a broad base for cultivating future translators[9][10]. Therefore, how to improve college English translation teaching has become an important research topic, so teachers should explore how to speed up the cultivation of translation talents to meet the urgent needs of the market [11].

\section{Problems in Translation Teaching}

Teaching Objects Are not Clear. At present, the training of advanced translation talents in colleges and universities mainly comes from two majors. The difference between the traditional translation of foreign language linguistics and that of translation masters is that the former focuses on mastering the research Methods, familiar with the theory of research, the latter focus on training to improve translation practice, and become a professional talent. In the actual translation of college personnel training, both the training objectives and programs are not very clear. In the study of the first batch of translation master's degree thesis in 2007, Murray (2011) found that in the cultivation of translation majors, there are still some problems such as serious academic orientation in teaching, insufficient translation practice of learners. Therefore, both the academic translation master or master of translation, are unable to meet the language service industry and industry needs.

Translation Ability Is not Conceptualized. In the definition of translation ability, Nordic (2006) points out that narrow-sense translation ability mainly refers to the ability of translation, generalized translation ability, besides language ability, cultural ability, professional ability and technical ability. In practice teaching, a common concept is that foreign language will be translated, in the teaching also focuses on the ability of learners to exchange language, for translation skills and other professional knowledge is relatively weak. The knowledge structure of translation talents includes three major parts: 
linguistic knowledge, translation knowledge and related professional knowledge. To improve learners' translation ability, we must break the traditional teaching mode and combine the concept of translation competence with the translation teaching And Translation Practice.

Teaching Mode and Method of a Single Obsolete. The requirements of the English syllabus are that the oral and written translation course is set up from the third semester and the semester is three semesters. The curriculum is simply set as an interpreter or a translation course. In the teaching content, tend to listen to reading and writing in all aspects of the basic language skills training, including the basic theory of translation, translation methods and strategies to explain, but rarely related to other related disciplines and knowledge of the use of translation tools. In the teaching mode, the basic use of traditional teaching methods, many teachers only in accordance with the content of teaching materials, teaching more than practice.

\section{Translation of the Reserve Talents in College English Teaching}

Translation of the Reserve Talents in College English Teaching for Non - English Majors. In reality, most of the western classics in China are translated by scholars in the fields of science, engineering, economics, history and philosophy. It is clear that these scholars are basically non-foreign professional backgrounds. Of the market practitioners, only $26 \%$ of the practitioners are foreign language professionals or translation professionals. Traditionally, it has been argued that the training of translators is a foreign language major and a translation major, but this is not the case. "In China, more than 80 percent of the western classics (not including literary works) are translated by scholars in the fields of science, engineering, history, philosophy, etc. Any scientist who is at the forefront of the academic field is often a translator. He is not only doing his own research, but also the introduction of Western academic thinking and advanced science and technology as their own responsibility. To be sure, many of the future of science and technology translation talent from the College English translation teaching, if we attach importance to college English translation teaching, you can make the majority of college students benefit.

From the market perspective, the market for non-foreign language background translation professionals have a great demand, our higher education personnel training must be market-oriented, accurate positioning, market segments must be divided, and take a variety of differentiated development the way. The development of China's economy, society and culture has put forward unprecedented demands on the quantity, type and quality of translators. It is obvious that the translation teaching of foreign languages cannot meet the needs of the market, which requires us to establish a multi-level training system. Lin Wusun pointed out that in order to adapt to the market demand for translation talents, translation teaching should be professional development, non-foreign language teaching should also bear the important task of cultivating translation talents, science and engineering or science and engineering university for translation students course. College English translation teaching is to adapt to the needs of market products, in the cultivation of translation talents play an important role, colleges and universities is the training of translation talents base.

From a student perspective, foreign language and translation professional students to engage in real translation is only part of the work, which translates the huge demand compared to talent, far can not meet the demand. The market demand for translation of talents scattered in all walks of life, and foreign language and translation professional training students are good at literature, politics, law, news, economy, management and other fields of translation work, they are mechanical, chemical, Electronic and other fields of translation work is difficult. Students of science and engineering have a good foundation to become a translator, these non-English majors or translation students of the language ability is not much worse than English majors, they have engaged in translation work in good condition, that is, non-English majors only Did not choose English as a professional, it does not mean that English is not good, and even some students higher than the English level of English students.

Professional Knowledge Courses + Translation Courses. Bilingual translation ability is the basic ability of the translator should have, in the translation practice, only the ability of bilingual translation is not enough, the translator need to translate and translate the language associated with cultural, scientific 
and technical knowledge Must understand, in order to come up with a good translation. With the translation industry more and more detailed division of labor, "specialized translation industry calls for a distinctive translation education (Xiao Weiqing, 2011)", translation teaching in teaching objectives and teaching methods should also be due to people, And translation courses must be combined with other professional courses in order to cultivate a "professional + characteristics" of translation talents. Many other domestic scholars think that we should consider our school, local characteristics, this article will be related to the curriculum is divided into literature courses and translation practice courses.

Literature Courses + Translation Courses. In the practice of cross-cultural translation, in order to avoid the translator's misinterpretation of the target language and the distortion of the target text, translation should be considered as a tool and means of cross-cultural and cross-cultural communication. The curriculum includes cross-cultural communication, British and American culture, Chinese culture, Western culture and the contrast between Chinese and Western culture and other literature courses, in order to compensate for the lack of cultural aspects of learners. The combination of translation courses and literature courses will help to improve the learners' super-linguistic abilities such as encyclopedic knowledge and topic knowledge, and help to strengthen the ability of individual translators to become professional translators.

Translation Practice + Translation. Translation according to the subject matter can be divided into literary translation and non-literary translation, the latter mainly related to engineering, pharmaceutical, legal, and economic and trade content. With the development of social economy and culture, there is a great demand for translation talents in various trades and professions. The demand for translation talents in translation market is not limited to literary translation. "If we do not consider market factors, Students do not understand other trades and other disciplines, do not understand the characteristics of other areas of translation, there is not enough vocational training, then how do they respond to the needs of the market (Xu Jun, 2010)? Therefore, the translation teaching should focus on training the application of the translation talents, translation industry or talent education to achieve real and professional hook.

The acquisition of learners' translation ability mainly comes from two aspects: one is to understand the nature, norms and standards of translation through cooperation between teachers and students or cooperation between students and students, to reflect on the translation practice and to understand the individual translation literacy; Of the translation task, the learners in the team to complete or individually complete a translation task, in the initial translation, modification, review, finalization and a series of translation output process, improve personal translation ability.

\section{On Translation Teaching in College English Curriculum}

College English Teachers Should Clear Their Ideas and Locate Correctly, Pay Attention to College English Translation Teaching. As with other English proficiency teaching, teachers should pay attention to the advanced teaching concept, the three-dimensional content of teaching contents and the modernization of teaching methods in translation teaching practice.

Output Drive Theory. In his later theory of output hypothesis, Swain pointed out that the activity of output language is an indispensable component in the second language learning process. The form of language output activity here mainly refers to speaking and writing; the driver of language output Function, Professor Wen Qiufang further pointed out: "Listening and reading, although the basis of the primary, but did not say, write, translation of external activities, understand and read the contents of the outside world cannot know." The output of the highest form of language, through the output of the translation activities, can make learners aware of the language skills, cultural ability and translation ability of the defect, and the expected solution to the problem, so as to achieve effective input and output.

Teaching Reform. In view of the phenomenon of "teaching more than practice" in translation teaching, translation teaching and education departments should strive to change the traditional "teacher-centered" curriculum model and gradually change to the "student-centered" subject model. In the teaching method, the teacher can take the integrated skills or teacher counseling gradually according to the professional content of the translation materials, and gradually show the dominant position of the 
learners in the translation practice. On the choice of teaching materials, teaching units should jump out of the restrictions on teaching materials, it is best not to specify the textbook, but practical examples of the use of translation materials. Through the establishment of a variety of classroom activities, so that the translation of the test of specific, and its concrete practice through the teaching activities in the curriculum to achieve effective output, such as on-site translation, group discussions, presentations, translation changes, teachers and students.

Translation Software and Technology Applications. In the development of information technology and the extensive use of computer software in today's society, a large number of translation tasks no longer rely solely on manual completion, with the help of human and machine to complete the calculation to improve the translation of the validity and accuracy of translation, the demand for a variety of information. Clearly, the advent of machine translation requires the translator to have some information technology. In order to meet the needs of the translation market for translation talents in the computer age, colleges and universities and personnel training institutions should consider the combination of translation courses and MT application courses. New Mode of College English Curriculum in the New.

At present, the translation of the market popular translation of professional software are: Trados, D éjà vu and SDLX, Jinshan and proper use of translation is relatively high frequency of general translation software, with the rapid development of mobile phone Android technology, The translation software mentioned above can be more convenient and quick to use on the mobile phone through Android. From the perspective of theory and reality, the Android system application to the translation of the learning method to add a new way, specifically on the translation of teaching, Android system, the expansion of the teaching of translation teaching content and denotation. This article envisages that the combination of translation course and Android translation learning software application in the new model of new curriculum can promote some new Android translation learning software to bring a new experience to translation teaching and learning. By combining translation practice, In the course of learners' acquisition of translation, the translation of college English courses to achieve the teaching effect.

\section{Summary}

On the one hand, the teaching objectives of translation practice teaching are not clear, and the methods and modes of translation teaching are relatively backward, which leads to the inability to meet the needs of the translation of translation talents. On the other hand, there are many problems in the process of translation talents cultivation. Market demand. The main purpose of this paper is to construct the new translation course model. The theoretical basis is to enhance the output of translation teaching to drive the learners' translation ability. The difference lies in the following aspects: Firstly, determine the course of "professional knowledge course + translation course" .Secondly, the teaching method is diversified and the teaching quality of translation course is improved. Finally, the quality of translation teaching and the translator's translation acquisition are tested concretely through translation practice. Therefore, the construction of college English translation curriculum model has important guiding significance for the cultivation of translation talents.

\section{Acknowledgments}

This paper was supported by the Science Foundation of Jiangxi Provincial Department of Education (GJJ14639,GJJ151547), Social sciences planning project of Jiangxi province(14yyq03),A Special Fund for Mid-aged and Yong Teachers as Visiting Scholars in Jiangxi General Undergraduate Universities. 


\section{References}

[1] Nord, Christian. Text Analysis in Translation: Theory, Method and Application of Translation. Oriental Text Analysis (Second Edition). Beijing: Foreign Language Teaching and Research Press, 2006.

[2] Merrill Swain. Output Hypothesis: Its History and Future. Foreign Language and Foreign Language Teaching. Chinese Translation, 40(1):45-51.(2008)

[3] MIAO Ju, GAO Gan, Constructing MTI Educational Characteristic Course .The Concept and Content of Technical Writing, 2:35-38. (2012)

[4] Yan Zhen, Back - up Power in Translating Talents in College English Teaching, Northern Literature, 2015-11-18

[5] LUO Xuan min,Translation Teaching in China: Problems and Prospects . Chinese Translation, 23(4):56-58. (2002)

[6] Dan Ting. The construction of knowledge structure of translation talents from translation teaching and teaching translation. Journal of Hubei Adult Education Institute,16(6):110-112. (2010)

[7] Ren Yuehua.Education of social demand on undergraduate courses of translation specialty. Journal of Guangdong Polytechnic Normal University (Social Science), 2: 109-111. (2009)

[8] $\mathrm{Xu}$ Hong.Operation of Theory and Skill in College English Translation Teaching. Journal of Changchun University of Science and Technology. (2011)

[9] Zhao Tianyu. A Probe into Translation Teaching in College English Teaching [J].Examination Weekly, 9: 155-156. (2009)

[10]Huang Zeying. Analysis of College English Translation Teaching Based on the Study of Translation Competence.Journal of Changchun University of Science and Technology.(2011)

[11] $\mathrm{Na} \mathrm{Hu}$, Xing Xu, Implications of Output Hypothesis in College English Translation Course,EMIM. (2015) 